\title{
A Sociolinguistic Study of the Emerging Trends in Igbo Personal Names
}

\author{
Geraldine Ifesinachi Nnamdi-Eruchalu \\ Department of English Language and Literature \\ Nnamdi Azikiwe University, Awka, Nigeria
}

\begin{abstract}
Ideally, personal names reflect the ideology, beliefs, values and norms of the bearers, and as such, an embodiment of their social identity. The current wave of westernization sweeping across Africa, especially the Igbo society, has influenced all aspects of her culture, including naming. Some of the names which were once regarded as nicknames have since been transformed to personal names, thus calling for scholarly investigations. The researcher argues that some of the current trends in naming stripe the names of their cultural, social, religious and political relevance, and blot the identity of the bearers, while others violate the norms of naming in Igbo culture. To provide the bases for comparison, the researcher compiled regular and trending Igbo names from her personal contacts in Awka, Anambra State, Nigeria, as well as from the social media, television and radio broadcasts, the internet and the print media for a descriptive analysis. Interview was also incorporated to obtain from the bearers of the names deeper insights into the motivation behind the names. It was observed that some Igbo names no longer have any meaning relationships with their derivatives, while others have experienced different levels of westernization. It is recommended that awareness campaigns should be deployed to educate the people on the interconnectivity of names, language, culture and identity so that they can place meaningfulness and relevance above fashion when it comes to personal names.
\end{abstract}

Key words: personal names, ideology, westernization, Igbo names, social identity

\section{INTRODUCTION}

One of the major ways of tracing a person's identity is by the personal name he/she bears. One's name makes him more of a member of one race, tribe, nationality, and religion than others. In situations where personal names are borrowed from cultures other than those of the bearers, the names are traced to their origins from where they derive their meanings and associations. In addition to meaning, names given to people say volumes about the circumstances of their birth, the dispositions of their parents, their belief system, their ideology, and the culture of the people.

The Igbo are one of the major tribes in Nigeria. They occupy the South Eastern states of Abia, Anambra, Ebonyi, Enugu and Imo States as well as parts of Delta, Akwa Ibom, and Rivers states in the South South region of Nigeria (Adibe 2009) ${ }^{1}$. Meanwhile, they are found all over Nigeria and in diaspora because they are very enterprising and innovative. The native tongue of the Igbo is the Igbo language, and since language is an integral part of culture, Igbo language reflects many aspects of the Igbo culture, including names and naming, and shapes the worldview of the people. Igbo names, like other names in other cultures are uniquely packed with meaning derived from their belief systems, philosophy, ideology, norms, and values. Below are some regular Igbo names and their meanings: 
A. Names that stress belief in the Almighty God (Chukwu Okike) and other gods and goddesses, and their powers and influences in the lives of human beings :

Igbo Name

1. Ebubechukwu

2. Chukwuemeka

3. Akachukwu

4. Ikechukwu

5. Ofokansi

6. Ofokaja

7. Chukwuemelie

8. Chidiebere

9. Chinazaekpere

10. Lotachukwu

11. Otuto

12. Chinyelugo

13. Onyinyechukwu

14. Amalachukwu

15. Chichetam

16. Odochi

\section{Meaning}

glory of God

God has done well

hand of God

God's power

Ofo is more potent than poison ( Ofo refers to the staff of office that symbolizes authority and sincerity in Igbo culture)

Ofo is more potent than sacrifice

God has won

God is merciful

God answers prayer

remember God

Praise

God lifted up

God's gift

Grace of God

God remember me

mercy shown by God

B. Names that depict the four market days of 'Eke', 'Orie/Oye', 'Afo', and 'Nkwo' in Igbo land. Children are named after the market day on which they are born.

\section{Igbo Name}

17. Okeke/Nweke

18. Mgbeke/ Nwanyieke

19. Nwoye/Okoye

20. Mgboye

21. Nwafo /Okafo

22. Mgbafo

23. Nwankwo/ Okonkwo

24. Mgbankwo
Meaning

male child born on Eke day

female child born on Eke day

male child born on Orie/Oye day

female child born on Orie/Oye

male child born on Afo day

female child born of Afo day

male child born on Nkwo day

female child born on Nkwo day.

C. Names that portray the import of wealth in the lives of the people. The Igbo respect wealth, and revere the rich. The rich also give themselves lofty names to display their riches. Examples of such names are:

\section{Igbo Name}

25. Akukalia

26. Akuabata

27. Akunna

28. Ubabike

29. Akajiaku

30. Ononujuaku

31. Obianujuaku

\section{Meaning}

when wealth is too much (it reaches everyone)

wealth has arrived (usually given to a female child born to a family where a girl is sought after to signal the riches that she will attract to the family especially at marriage)

wealth of the father (same as in Akuabata)

wealth is strength

A rich person

One in the midst of plenty of wealth

One who was born to the family at a time of plenty. It shares this meaning with Obiageliaku. 
32. Ugboaku

33. Iteego

34. Ojiegonekwu vehicle that carries money (a gir's name)

pot of money

one who has money has the say

D. Some names also stress the importance of children in Igbo culture. They include: Igbo Name

35. Nwakaego Meaning

36. Nwabundo child is more valuable than money

37. Nwamaka child is shelter

38. Nwakanma child is precious child is better

E. These names represent the philosophy and worldviews of the Igbo toward life, relationships, fate, death. Igbo Names

39. Onwuegbuchula

40. Ilokanuno

41. Udokanma

42. Igwebuike

43. Onwudinjo

44. Adaora

45. Nkiruka

46. Ndubuisi

47. Ekwutosi

48. Anulika

49. Ndukaku

50. Maduaburochukwu

51. Nkemakolam

52. Madukaku

53. Onyemaechi

54. Agbapuluonwu

55. Udemezue
Meaning

premature death should not come

enemies are people of one's household

peace is better

there is strength in number

death is evil

the daughter of the people

better days are ahead

it is life that matters

do not condemn others

happiness is better

life is more valuable than wealth

the ways of man are different from the ways of God

May I have my own

it is better to have relatives than to have wealth who knows tomorrow

you cannot run away from death

my fame has gone round

F. Names that throw a challenge as if there is a contest going on in which one must declare his/ her stand are also exemplified below:

Igbo Name

56 Asimonyekwuna

57. Ginigaeme

58. Onyekamike

59. Aganekwu

60. Ibuchukwu

61. Onukwube

62. Okaka

\section{Meaning}

Have I asked anybody not to talk?

what can happen?

who is stronger that I?

one must be talking.

Are you God?

people can say what they like

the greatest

G. Some names portray the opinions, emotions, and experiences of the parents or family prior to the coming of the child. They include:

\section{Igbo Names}

63. Iheanacho

64.Somadina

65. Kamsinyochukwu

66. Onuegbunam

\section{Meaning}

what is being sought after

I shall not live alone

God has done exactly what I asked from him gossips/insults will not stop me 
67. Chimamanda

68. Chinasaramokwu

69. Onwuegbuzina

70. Umeziluike my God will never fail

God responds to all that have been said about me death do not kill again (especially where there has been series of deaths)

loses do not torment me further

\section{H. Some others are given by parents to praise their babies' beauty or circumstances of birth. They include: Igbo Name \\ Meaning}

71. Ugonma

72. Ugonna

73. Olaedo

74. Olanma

75. Akwaeke

76. Akwaugo

77. Mkpulumma

78. Agbomma the beautiful eagle

the eagle of her father

jewel of gold

ornament

the egg of the python (a rare breed)

the egg of the eagle (a rare breed)

the seeds of beauty

epitome of beauty

Having established that meaningfulness and relevance are of the essence in Igbo names, this study seeks to investigate into trending names borne by the people to ascertain whether they still retain those meanings and relevance. Consider the following Igbo names:

$\begin{array}{llll}\text { Name } & \text { Translation } & \text { Clipped Form } & \text { Meaning } \\ \text { 79. Obinna } & \text { mind of God } & \text { Obi } & \text { mind } \\ \text { 80. Adaeze } & \text { daughter of the king } & \text { Ada } & \text { daughter } \\ \text { 81. Okechukwu } & \text { portion from God } & \text { Oke } & \text { portion } \\ \text { 82. Oyedikachi } & \text { Who is like God } & \text { Onyedika } & \text { who is like } \\ \text { 83. Chioma } & \text { good God } & \text { Chi / Chi Chi } & \text { 'Chi' is Igbo word for God }\end{array}$

Names are clipped, shortened or abridged to make them simpler, more cute and more endearing as found in the examples above. 'Obi', 'Ada', 'Oke', 'Onyedika' and 'Chi' or 'Chi-Chi' in the example above do not convey the full meanings of the names from which they are derived, but they provide some clues from which their meaning could be worked out. Clipping is a productive process of word formation in many languages of the world, including Igbo. It is the process of forming new words by removing a syllable(s) from parts of an existing word, while retaining a syllable(s) that conveys the full meaning of the word. 'Flu', 'fridge', 'plane; are all formed by clipping off syllables from 'influenza', 'refrigerator', and 'aero plane' respectively. In addition to clipping, Igbo names are also substituted to reflect the beliefs of the bearers especially when they are dissatisfied with the connection they evoke in idol worshiping or other aspects of Igbo belief systems. Here are examples:

$\begin{array}{llll}\text { Name } & \begin{array}{c}\text { Meaning } \\ \text { child of the deity }\end{array} & \text { Derivative } & \begin{array}{c}\text { Meaning } \\ \text { child of God }\end{array} \\ \text { 85. Nwalusi } & \text { child of osu } & \text { Nwachukwu } & \text { child of God } \\ \text { 86. Nwosisi } & \text { child of the tree } & \text { Nwachukwu } & \text { child of God } \\ \text { 87. Onwuka } & \text { death is greater } & \text { Chukwuka } & \text { God is greater } \\ \text { 88. Okololbono } & \text { son of Ibono } & \text { Nwachukwu } & \text { child of God }\end{array}$

Note that the osu is a person dedicated to the idol. They are discriminated against in Igbo society. Also, Ibono is a deity.

The main thrust of this study is in the rate and manner in which the young and the old, the educated and the uneducated, the rich and the poor, the privileged and the underprivileged, 
the urban dweller and the rural dweller westernized their Igbo names. Nneka (mother is supreme) is now Nekky; Chioma (Good God) is now 'Chaioma' or 'Chommy'; Onyedikachukwu is now 'Katch' or 'Katchy'. 'Ngozi' (blessing) now simply answers 'NG', 'Nkolika' (it is better to live to tell the story) answers 'NK', while 'Uchechukwu' is now 'UC'. Some individuals and families now prefer to change their last names from Igbo names to 'Johnson', 'Paul', 'Godwin', all of which are of western origin. These names do not evoke any connections in Igbo worldview. They have been westernized. Their phonology and spellings also violate both the phonological and spelling rules of the Igbo language. It is now impossible to trace many Igbo people to their hometowns from the personal names they bear. This researcher argues that the current trend in naming in Igbo society is contributing to the erosion of the Igbo cultural values and worldviews which a people's culture implicit in their names inculcate in them. Westernized names are imposing strange identities on the bearers; making them half Igbo and half western. This is a major indicator for language shift.

Shortening of Igbo personal names has attracted the attention of researchers. Onyegbule $(2014)^{2}$ seeks to establish that Igbo personal names are embedded with meanings that reflect Igbo culture. The analysis of the data she obtained through personal observations, interviews and questionnaire reveal that abridging the names obscure their true meaning. Also, in 2015, Ezenwa-Ohaeto $^{3}$ studied name clipping in the Omambala cultural zone of Anambra state with a view to discovering its sociolinguistic import. She sought to establish a connection between the misinterpretation of clipped names and language growth or death in the cultural zone. She discovered that extreme name clipping stripes the names of both meaning and cultural and historical importance. It also places a death sentence on their dialect of Igbo.

This researcher seeks to investigate into the emerging trends in Igbo personal names with a view to discovering their patterns, the motivations behind them, and their social and cultural relevance. This study has become necessary at this point that the language is experiencing a major shift to the English language, and so will add to the existing literature on language shift, language maintenance and language loss in Africa. The following research questions will guide the analysis:

1. What are the emerging trends in Igbo naming patterns?

2. What are the motivations behind the changes in Igbo naming pattern?

\section{Name}

Name points to the bearer which could be humans, trees, places, concepts. It makes the thing named distinct from others of their kind. The New International Comprehensive Dictionary of the English Language defines name as "the distinct appellation by which a person or thing is known (2003, p. 842) ${ }^{4}$. The New Encyclopedia Britannica states that "a name is a word or group of words used to refer to an individual entity (real or imaginary); the name singles out this entity by directly pointing to it" $(2003, \text { p. } 733)^{5}$. There are many categories of name depending on what is named - waters, hills, animals, but this investigation is limited to personal names.

A personal name is a name that belongs to an individual and which serves as a label for him or her. It is the distinct identity which every individual bears. It is the standard practice in all cultures for every individual to be named at birth. The United Nations CRC Article $7(2)^{6}$ hints that "every child should be registered immediately after birth and shall have the right from birth to a name", and this has been going on for as long as human memory can recollect. Different cultures maintain different naming practices. In some cultures people are given just one name as their personal names, while in others, personal name is made up of different kinds of names the most outstanding being two given names and a surname. It is the second naming 
practice that Blount refers to in this assertion, "it is made up of a first name, middle name and a surname of last name all of which jointly address that person, and makes him distinct from even members of his or her own family" $(2015, \text { p. } 1)^{7}$. This practice is common among the Igbo. Their Given names consist of a first name which is usually a Christian name, and which could be western or Igbo in origin, and an Igbo name. Their surname is essentially patronymic as the Igbo have no inheritance in their mother's (maiden) home.

\section{Naming in Igbo Culture}

We should love our language and live our language by giving our children Igbo names, for our culture is our essence as a people. (Anyachonkeya 2014, p. 121) ${ }^{8}$

The Igbo people are bound by tradition to hold a formal naming ceremony for new born babies immediately after birth or at the end of seven market weeks (the Igbo market week is made up of the four market days named Eke, Oye/Orie, Afo and Nkwo), twenty eight (28) days, after birth. Where it holds after seven market weeks, the newborn goes with a temporary name derived from the circumstances of its birth. In the remote past, and currently in some parts of Enugu state, an elderly member of the newborn's family goes to consult diviners to reveal its name. At the official naming ceremony, the newborn is given the name revealed by divination by the oldest man in the village or community or the kindred, before other people start naming the newborn, bringing gifts along as they come. In some other areas, it is the newborn's father that names it first. This practice gives rise to people having many names, sometimes over fifty depending on the number of people present at the naming ceremony.

Igbo names are at times, names of departed family members of either parents, believed to be reincarnated in the baby. At other times they are praise names for the gods and ancestors; names that mirror the philosophy of the Igbo people, or point to the child's destiny and circumstances of birth. Osuji states that:

the Igbos attach great significance to names hence newborn babies are given meaningful and significant names. The Igbos invariably do not believe that there is nothing in name. Rather they believe, and their culture supports it that a person's name has a lot to tell about him, his background or about his parents (1998, p. 157)9.

Parrinder observes that the names given to Igbo children are reflections of some special circumstance of birth or place in the family: one of a twin, one born after twins... with a cord round its neck, feet first, with extra fingers, with face downwards, at the new year, on a holy day, with the mother dying at birth, when the father is away hunting, and a number of other occasions. (92-93)10.

Many of these practices are gradually being phased out by westernization. Many Igbo parents due to their education, jobs, exposure, Christian orientation, and others no longer pay attention to Igbo language and culture. Okodo observes that:

some iconoclasts in Africa and the Black in diaspora show dislikeness (sic) for their mother tongue. They do this by giving high frequency to foreign languages in their day -to-day expressions, even when they are attending meeting among their kith and kin. They speak English, Portuguese, or Arabic, as the case may be, to boast their ego of the acquisition of foreign education (2005, p. 57) ${ }^{11}$.

Most of these people give their children names of their choice in the city, and have neither the time to consult any person on the name for the child nor conduct a formal naming ceremony for the children. Some of them answer and also give their children such names that bastardize the Igbo language and culture. 


\section{Language and Culture}

It is essential to explore the relationship between language and culture especially as naming in all societies deals with meaning and associations drawn from the culture of the people, or a foreign culture from which a foreign name originated. Language is a property of society by means of which all human interactions are conducted. No human society can exist without this powerful medium of communication. Language is the tool for the transmission of culture from one generation to another. Culture is a set of socially acquired knowledge, and since language is acquired and used in relation to other members of society, it is an aspect of people's culture. Goodenough 1957 comments as follows:

As I see it, a society's culture consists of whatever it is one has to know or believe in order to operate in a manner acceptable to its members... Culture, being what people have to learn as distinct from their biological heritage, must consist of the end-product of learning: knowledge, in a most general ...sense of the term (quoted in Hudson 2001, p. 71$)^{12 .}$

Language is implicated in this kind of knowledge. Meanwhile, some anthropologists view culture as material culture, which includes artefacts, music, dance, cuisine, attire and others. From whichever way one views culture, it is that knowledge that people must possess in order to live normal daily life with other people. One's behavior must conform to the culture of the people one lives with.

According to Akindele and Adegbite language and culture are connected in three major ways: First, it is an aspect of culture - one of the very many objects and institutions of culture. Second, language is an instrument of thought. It helps to concretize thought and also to explore, extend and record the experiences in a culture. Third, language expresses culture. It is the only way by which the social experiences and values of a group of people are perceived and understood. $\left(2005\right.$, pgs. 5-6) ${ }^{13}$.

Edward Sapir studied the relationship between language, culture and personality, and argues that the physical world is unconsciously built up on the language habit of people. Language habit of people determines the choices of interpretations they make (Wardhaugh 2010) ${ }^{14}$. Benjamin Lee Whorf, developed Sapir's ideas further, and observes that language conditions our worldview (Wardhaugh, 2010. We see things in the real world from the perspective of our individual languages. This is the theory of Linguistic relativity. Linguistic relativity engenders cultural relativity. The idea behind this is that people live in different worlds due to their different languages. Linguistic relativity is an aspect of Sapir-Whorf Hypothesis.

Since language and culture are intimately related, Igbo names represent Igbo cultural values and as such reflect Igbo ideologies and worldviews. Hence, the meanings and associations which Igbo names evoke are best preserved in Igbo language. Modernizing these names blurs their 'Igboness', and makes them meaningless both in the Igbo and English cultures.

\section{Sociolinguistics, Language Shift, Language Death, and Language Maintenance}

Sociolinguistics is a branch of linguistics which studies the relationship between language and society. It is concerned with the study of how society influences linguistic choices. Language shift, language maintenance and language death have attracted the attention of contemporary linguists. When languages come in contact in a society, it is commonplace for the people to embrace the one with more political and social relevance while leaving theirs. The dominant language spreads and penetrates the cultural domains of the society, while the dominated one begins to shrink and with time is endangered. It is the replacement of one language by another in society that is called language shift. Ostler defines it as "a process or event in which a 
population changes from using one language to another" $(2017, \mathrm{np})^{15}$. In the words of Tsitsipis a language undergoes shift when "the codes under scrutiny are being progressively or more suddenly replaced by other languages in speakers' repertoire, with structural consequences for the receding codes, and socio-cultural repercussions for the community involved" $(2017, \mathrm{np} \text {. })^{16}$ . When the society realizes that its language is endangered and may die, and decides to continue to use it in spite of the dominant language threatening its existence, the society is involved in Language maintenance. Once a shift is completed, the language dies. "A language dies when nobody speaks it any more" (Crystal 2003, p. 1) ${ }^{17}$. A language that is no longer transmitted to the younger generations of the speakers dies off naturally when the last adult speaker dies. The Igbo language, like many African languages has been undergoing shift since it came in contact with the English language during the colonial times.

\section{The Invasion of Igbo Land by Britain}

There is no gainsaying that in Africa, especially in the Igbo society, some obnoxious cultural and religious practices like killing of twins, human sacrifice, abandoning of people suffering from 'abominable' ailments to die in 'evil forests' were rife. The invasion and conquest of Igbo societies by Britain destroyed her culture and traditions to their very fabrics. The people who had been living in fear of some of the traditions forsook them and embraced the invading western culture which seemed more liberal and non-discriminatory. In fact, the imposition of entirely new values culminating in western education, urbanization, white collar jobs, an exotic and elitist language, civilization, and a host of others constituted a major blow to the primordial traditional worldview of the Igbo. No wonder Isichei observes that in addition to religion

The overthrow of Iboland's politics, the power of the Oyibo with his different values and irresistible technology, the rapid rise of those with skills which could be utilized in the new system - all these seemed to throw the entire inherited order into question. Traditional society was based on a network of commonly accepted values, duties, and expectations. Now the fabric was threatened. (1973, p.181)18.

Adibe also states that

The incursion of western civilization with its urbanization, western education, industrialization and new religious doctrines brought about new orientation to Igbo people's modern worldview. This western civilization bastardized Igbo centralized cultural value system in individual and communal quest within political, religious and economic well-being. (2009, p. xv)

They abandoned their culture in favour of the western ways of life. Isichei enthuses that:

...Africans developed an inferiority complex and began to copy blindly European culture and ways of life, and to despise African traditions and customs. Thus a great deal of what was good in African culture such as respect for truth and honesty, and respect for tribal law and customs were superseded by the bad aspects of European character (1973, p. 279)

Ladies and young girls of today wear bikini or leggings with singlet to occasions that require formal clothing; noodles and canned food have become the staple food of many homes even in the villages; many mimic westerners in their speech; some use bleaching cream to lighten their complexion, while some undergo cosmetic surgeries to appear western. Of interest to this study are the excessive shortening of Igbo names to resemble western names, replacing the names with western ones and other practices that violate the original status of Igbo names. These practices most often stripe the names of any iota of meaning. 


\section{METHODOLOGY}

The majority of the names used in this study were collected from the personal contacts of the writer in Awka, Anambra State, Nigeria where she lives and works. Her status as a lecturer in a federal university in the heart of Igbo land acquainted her with many Igbo staff and students who bear these emerging names. Names were also collected from television and radio broadcasts, the print media, social media and the internet. Interviews were also incorporated in the methodology to provide the information that will facilitate an in-depth understanding of the motivation behind the social situation. Twenty five persons chosen by purposeful selection from the people who answer the different categories of the emerging naming patterns in Nnamdi Azikiwe University, Awka were interviewed to discover what the names mean to them, and why they answer them. The data were organized in such a way as to provide answers to the research questions.

\section{RESULTS}

Research Question 1: What are the emerging trends in Igbo naming system? The new trends in naming in Igbo land have been observed to include:

$\begin{array}{lll}\begin{array}{l}\text { A. Excessive clipping of Igbo names as in the following: } \\ \text { Name }\end{array} & \text { Meaning } & \text { Clipped form } \\ \text { 89. Chineze } & \text { God Protects } & \text { Chinny } \\ \text { 90. Obinna } & \text { Mind of God } & \text { Obyno } \\ \text { 91. Ikechukwu } & \text { God's power } & \text { Iyke } \\ \text { 92. Nnamdi } & \text { my father is alive } & \text { Andy } \\ \text { 93. Chinelo } & \text { God thinks about me } & \text { Nelly } \\ \text { 94. Sopuluchukwu } & \text { Respect God } & \text { Sop } \\ \text { 95. Chukwuemeka } & \text { God has done well } & \text { Mekus } \\ \text { 96. Chimamanda } & \text { My God will never fail } & \text { Mandy } \\ \text { 97. Chimobi } & \text { God knows my desire } & \text { Moby } \\ \text { 98. Amaechi } & \text { Is tomorrow known? } & \text { Meche } \\ \text { 99. Chike } & \text { God is strength } & \text { Chayk/ Chayko } \\ \text { 100. Adaobi } & \text { Daughter of the 'Obi' } & \text { Doby } \\ \text { 101. Chinonyelum } & \text { God be with me } & \text { Nonny } \\ \text { 102. Chukwunonso } & \text { God is near } & \text { Nonny } \\ \text { 103. Oluchukwu } & \text { Work of God } & \text { Olay } \\ \text { 104. Chizobam } & \text { God save me } & \text { Zobby } \\ \text { 105. Onyedikachi } & \text { Who is like unto God? } & \text { Katch/ Katchy } \\ \text { 106. Nkechinyelu } & \text { the one given by God } & \text { Ketch/ Ketchy } \\ \text { 107. Uchenna } & \text { will of God } & \text { Auchman } \\ \text { 108. Chukwuebuka } & \text { God is so great } & \text { Bukky/ Bukas } \\ \text { 109. Onyebuchi } & \text { Who is God? } & \text { Bukky } \\ \text { 110. Chisimdi } & \text { God tells me to live } & \text { Sid } \\ \text { 111. Tochukwu } & \text { Praise God } & \text { Toks } \\ \text { 112. Chinazaekpere } & \text { God answers prayer } & \text { Zara } \\ & & \end{array}$

A look at most of these clipped names shows that they are neither Igbo in speech nor in writing. They are also not English words in spite of the attempt to anglicize them. They do not have any meaning relationship in any of the two languages. Meanwhile, some of these clipped forms are identical and are capable of creating ambiguity. 
B. Use of initials clipped from Igbo names. Examples:

$\begin{array}{lll}\text { Name } & \text { Meaning } & \text { Initials } \\ \text { 113. Ngozi } & \text { Blessing } & \text { NG } \\ \text { 114. Nkolika } & \text { it is better to be alive to tell the story } & \text { NK } \\ \text { 115. Udechukwu } & \text { the fame of God } & \text { UD } \\ \text { 116. Uchenna/Uchechukwu will of God } & \text { UC } \\ \text { 117. Ijeoma } & \text { journey mercies } & \text { IJ } \\ \text { 118. Ujunwa } & \text { in the midst of many children } & \text { UJ } \\ \text { 119. Ndidiamaka } & \text { patience is a virtue } & \text { ND } \\ \text { 120. Ndubuisi } & \text { Life is the ultimate } & \text { ND } \\ \text { 121. Ojemba } & \text { traveller to places } & \text { OJ }\end{array}$

These initials have become popular among the people who bear the names from where they were clipped. Though the names are Igbo, the abbreviated letters are pronounced using English alphabets. Yet, a good percentage of the people cannot recite the alphabets of their language.

C. Outright replacement of Igbo surnames with English ones:

$\begin{array}{llll}\text { 122. Godwin } & \text { 123. Maxim } & \text { 124. Peter } & \text { 125. John } \\ \text { 126. Paul } & \text { 127. Harrison } & \text { 128. Simon } & \text { 129. Victor } \\ \text { 130. Sunday } & \text { 131. Abraham } & \text { 132. Collins } & \text { 133. Michael } \\ \text { 134. Loveday } & \text { 135. Mathias } & \text { 136. Benson } & \text { 137. Israel } \\ \text { 138. Geoffrey } & \text { 139. Thomas } & \text { 140. David } & \text { 141. Bernard } \\ \text { 142. Star } & \text { 143. Daniel } & \text { 144. Dominic } & \text { 145. Joseph } \\ \text { 146. Moses } & \text { 147. Samuel } & \text { 148. Eric } & \text { 149. Benjamin }\end{array}$

Many Igbo persons and families have dropped the surnames by which they have been known and identified, and opted for western names as replacements. It is now difficult to discern from their westernized surnames who they are and the part of Igbo land they came from. Before now, for instance, you could guess with certainty from somebody's surname that he is from Nsukka, Onitsha, Abakiliki, but today, those westernized surnames have closed that access.

\section{Compounding of names. The names are linked with a hyphen. These take different forms as shown below:}

i. a western first name and an Igbo surname

This consists of a man's Christian name and his surname answered by the members of his immediate family as their surname. Examples:
150. David-Ositadinma
151. Jeff- Anyamene
154. Frank-Udeh
152. Ben- Ndukwe
153. Ben-Okoye
157. David - Osita
155. Allen-Odum
156. Sam- Okeke
160. Ralph-Uzodinma
158. Ben-Emenike
161. Dan-Wachukwu

ii. A middle name and a surname. A man's middle name which is most often an Igbo name is compounded with his surname and answered as a surname by his immediate family. Example:
162. Chidi-Onuora
163. Nnamdi-Eruchalu
164.
Nduka-Ohanwa
165. Enemuo-Uzoezie
166. Ezenwa-Ohaeto
167.
Jisieike -Onuigbo
168. Njoku-Oji
169. Ifeanyi-0bidinma
170.
Buchi- Okafor
171. Nnamdi-Oguno
172, Ifeanyi-Okafo
172. Okey-Odezue 
iii. Some married ladies bear a compound surname formed from their maiden surname and their husband's surname. Examples:
173. Okafor-Ozoemena
174. Uto-Ezeajugh
175. Njoku-Oji
176. Jideani-Onodugo
177. Ude-Ezekwesili
178. Eze-Ugwueze
179. Nebo-Eze
180. Onyia-Okonkwo
181, Eze-Ezeadiefe

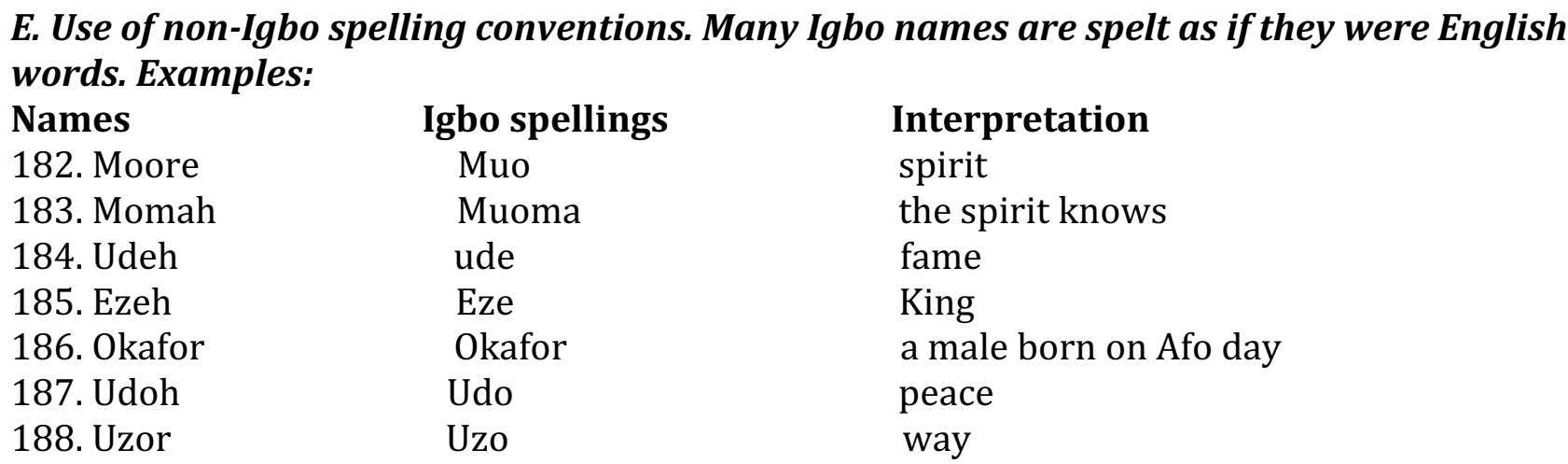

The spellings of the names in column A are anglicized, while those in column B are their original Igbo versions. The bearers of the names prefer to use the spellings in column A and regard those who use the Igbo spellings as being uninformed.

\section{Research Question 2: What are the motivations for the trends in Igbo naming pattern?}

The interviewees gave different reasons for adopting the different naming patterns, and these are discussed below:

Three of the five respondents interviewed for over-clipped names said they clipped their names to make them more alluring, more trendy and more fashionable, and have never thought about whether the derived form is meaningful or not. Asked whether they will discontinue the use of the names they said they loved the names and would rather retain them. The remaining two said that the clipped names make them more popular and more outstanding than their namesakes who answer the full names.

Four of the interviewees who answer abbreviated names said that the names are brief, cute, and trendy. One of the four observed that abbreviating the names makes them newer and better, than the old and overused names forms from which they were coined. One of them said his friends gave him the name and because they like it he started answering it. Asked whether the abbreviated names can be called in Igbo instead of English, all of them said no.

Among those who had their Igbo surnames replaced with western names, two said they grew up answering the surnames. When asked how their families got the names, they responded that they were their grand fathers' names. Of the remaining three, two said that conflicts in their extended families compelled their fathers' to change their Igbo surnames to their fathers' first names which happened to be westernized names. The last one was a lady who said she was feed up with circumstances surrounding her life and her family and decided to change her Igbo surname to an English one that denotes progress. Asked about how they feel answering such names in the midst of their fellow Igbo who would want to know their identity they all maintained that they are comfortable with it. Meanwhile, two of them hinted that there are times they really do want to cover their identity, and that the western name does it perfectly.

Three interviewees who answer a compound surname made up of a western first name and an Igbo surname said the names are their fathers' names, while two said they are their husbands' 
names. When asked why they decided to answer the names the first three interviewees said they grew up answering those as their surnames, while the last two said they agreed with their husbands that they and their children would answer the names.

The same applies to those who bear a compound surname made up of an Igbo name and a surname. One of the interviewees said the name is his father's name, while the remaining four said they are their husbands' names. Three of the women said their husbands elected to make members of their immediate families answer their given names because they want them to be identified with them, not the larger family, while one said that she and her husband decided that they would answer his given names because many young families are doing so.

Of the five ladies interviewed for compounding their maiden surname and their husbands' surname, one of them gave two reasons for doing so. She wanted to stay connected with the virtues her father brought to their surname. The name is synonymous with education and hard work in their town. Secondly, she had published some works before she got married and wanted to stay connected to those professional accomplishments. Another one said she was already well-known professionally with her maiden name before she got married, and because she did not want to loss that identity she added her marital surname to her name. The remaining three said they had admired people who combined the two surnames, so when they got married they did the same.

On the use of non-Igbo spelling convention to write Igbo surnames, four of the interviewees said they have always known their surnames to be spelt the way they are, while one said he stated closing his surname with a '- $r$ ' when he noticed that people who share the same surname with him do so. When asked if they can begin to spell their names correctly in Igbo language, they responded in the negative.

\section{DISCUSSION}

The naming system in Igbo land has been seriously undergoing remarkable changes attributable to the shift towards English which the language is currently undergoing. This study aims at exploring the different dimensions of changes which are taking place in the Igbo naming system, as well as the motivations for them. It has been established in this paper that Igbo names are full of meanings drawn from the culture, social, religion, and philosophy of the people. The change in the orientation of many Igbo people occasioned by the wind of westernization blowing across Africa has bastardized many Igbo names and stripped them of meaning and relevance in the Igbo worldview. Excessive clipping, abbreviation of names with a subsequent anglicized pronunciation of the abbreviated letters, compounding, use of westernized names as surnames, adoption of English spelling convention for Igbo names have all been identified as the emerging trends in the Igbo naming system. The motivations for the excessive clipping and abbreviation of names are that the clipped names are trendy, fashionable, brief, and cute, unlike their original sources which are long and boring. Reasons ranging from the desire to give one's identity to the members of one's nuclear family, and the desire to retain the maiden names for professional and other social reasons were given for compounding of names to form surnames. Family feuds/disagreements, the desire to prosper, the desire to be independent of other family members, and the desire to dissociate self from other family members for some religious and other social reasons are some of the reasons for replacing Igbo surnames with English ones. Some also drop their Igbo surnames for westernized ones to hide their identity. Those that spell their names by adopting the English spelling conventions do so because they thought it is right. None of them could justify the reason for adopting the English spelling conventions. 
These new trends in the Igbo naming systems are anomalous in the context of the language and culture of the people. None of them was used in the traditional Igbo society. They are all offshoots of colonization, yet the people are not relenting in chasing after them. Since these observations confirms Tsitsipis (2017) assertion above that a shift results in "structural consequences" for the language "and socio-cultural repercussions for the community involved", it is not odd to state that Igbo language is under threat of extinction if these linguistic sabotage continue unchecked. This paper serves as a call for the reorientation of the Igbo to guard what is left of their culture by preserving the original meanings of their Igbo names as their worldview are summed up in them. The people should begin to deconstruct the impact of colonization and imbibe the culture of language maintenance to save their language from imminent death.

\section{References}

Adibe, G. E. (2009). Igbo Issues: Values, Chi, Akala Aka, Magic, Agwu and Manipulation of Divinities. Onitsha: Midfield Publishers Limited.

Onyegbule, J. N. (2014). Personal Names as a Mirror of Igbo Culture: A sociolinguistics Approach. Nnamdi Azikiwe University: Unpublished project.

Ezenwa-Ohaeto, N. (2015). Sociolinguistic Import of Name Clipping Among Omambala Cultural Zone of Anambra State, Nigeria. CSCanada Studies in Literature and Language. Vol 10 (3). pp 77-82. Retrieved on 29th December, 2017 from www.cscanada.org

The New International Webster's Comprehensive Dictionary of the English Language (Encyclopedic Edition). (2003). Trident Press International.

Encyclopedia Britannica. Vol. 24. (2003). Macropedia. (15 ${ }^{\text {th }}$ ed.). Edinburgh: Encyclopedia Britannica Inc.

United Nations General Assembly Convention on the Rights of the Child. Article 7 (Part 1). (1989). Retrieved on $2^{\text {nd }}$ February, 2018 from www.un.org

Blount, B. (2015). "Personal Names" in Taylor, John R. (Ed.). The Oxford Handbook of the Word. Retrieved 2nd February, 2018 from www.oxfordbibliographies.com

Anyachonkeya, N. (2014). Naming in Igboland: A Linguistic and Cultural Study. Mediterranean Journal of Social Sciences.

Osuji, C. (1998). Foundations of Igbo Tradition and Culture. Owerri: Opinion Research and Communications Inc. Parrinder, G. (1974). African Traditional Religion (Third ed.). London: Sheldon Press.

Okodo, I. (2005). On the Explanation of Culture. Awka: Unizik Journal of Arts, Vol vii.

Hudson, R.A. (2001). Sociolinguistics. Cambridge: Cambridge University Press.

Akindele, F. and Adegbite, W. (1999). The Sociology and Politics of English in Nigeria: An Introduction. Ile Ife: Obafemi Awolowo University Press Ltd.

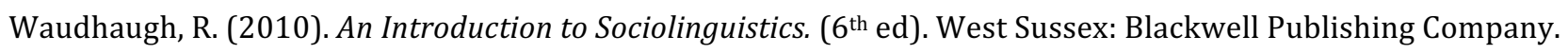

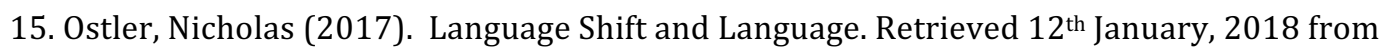
www.oxfordbibliographies.com.

Tsitsipis, L. D. (2017). Language Shift and Maintenance. Retrieved 19th January 2018 from www.eolss.net Crystal, D. (2003). English as a Global Language. (Second ed.). Cambridge: Cambridge University Press Isichei, .E. (1973). The Ibo People and the Europeans: The Genesis of a Relationship - To 1906. London: Faber and Faber Limited. 